DOI: 10.32844/2222-5374-2020-104-2.27

УДК: 342.9

Люх В. В.,

здобувач Науково-дослідного інституту публічного права

\title{
ІНСТРУМЕНТИ АДМІНІСТРАТИВНО-ПРАВОВОГО ЗАБЕЗПЕЧЕННЯ ФІНАНСОВОЇ БЕЗПЕКИ ДЕРЖАВИ
}

Стаття присвячена аналізу проблематики інструментальної складової в адміністративно-правовому механізмі забезпечення фінансової безпеки держави. Акцентовано, що трансформація у сучасній адміністративно-правовій доктрині категорій “форми діяльності публічної адміністрації” та “методи діяльності публічної адміністрації” у категорію “інструменти публічного адміністрування" актуалізують дослідження саме інструментів адміністративно-правового забезпечення правоохоронними органами фінансової безпеки держави. Встановлено, що у сучасній правовій доктрині застосовується широкий підхід до визначення категорії "правові інструменти", згідно з яким інструменти - це весь комплексів засобів правового регулювання/впливу, та запропоновано конкретні інструменти діяльності публічної адміністрації розкривати через призму системи їі інституціонально-функціональних характеристик. Визначено, що правоохоронними органами в процесі забезпечення фінансової безпеки держави використовуються такі інструменти публічного адміністрування як нормативні акти, адміністративні акти, адміністративні договори, плани та фактичні діі. Під нормативним актом як інструментом адміністративно-правового механізму забезпечення фінансової безпеки держави запропоновано розуміти виданий уповноваженим суб'єктом юридичний акт, у якому закріплено норми адміністративного права, які регламентують відносини у фінансовій сфері між публічною адміністрацією та іншими суб'єктами, які мають публічний інтерес у цій сфері. Виділено особливості нормативних актів як інструменту забезпечення: загальні формальні параметри, пов'язані з інституційно-процедурними аспектами (компетенція, порядок, форма і т.n.); спеціальні матеріальні параметри (публічність; адресність; юридична обгрунтованість і значущість; нормативність; односторонність; підзаконність; недискримінаційний характер). Зазначено, що адміністративні акти за своїми сутнісними рисами $\epsilon$ новою категорією для доктрини адміністративного права, зміст яких розкривається через повноваження публічної адміністрації, $і є$ наслідком імплементації законодавства України до права Європейського Союзу, що обумовило перехід від використання терміна «акт державного управління» до поняття «адміністративний акт». 3 огляду на відсутність легальної дефініції адміністративного акта в Україні, в якості базового застосовано розуміння сутності адміністративного акта як рішення суб'єкта публічної адміністрації щодо вирішення конкретної адміністративної справи, яке тягне юридичні наслідки для конкретних фізичних і юридичних осіб, що 
відповідає сутності досліджуваного інструмента діяльності публічної адміністрації в частині забезпечення фінансової безпеки держави. Виокремлено фундаментальні ознаки адміністративного договору у сфері фінансової безпеки держави - наявність публічної адміністрації як однієї зі сторін такої угоди, а також сутнісні характеристики щодо обумовлення повноважень сторін договору на основі владно-управлінської функції. Іншими факультативними специфічними інструментальними рисами адміністративного договору в фінансовій сфері є орієнтація на задоволення публічного інтересу та суспільних потреб у фінансовій безпеці, законодавчі процедурні рамки діяльності суб'єкта публічної адміністрації, спрямованої на реалізацію його адміністративної компетенції.

Ключові слова: публічне адміністрування, фінансова безпека держави, правовий інструмент, інструмент адміністративно-правового забезпечення, правоохоронний орган, нормативний акт, адміністративний акт, адміністративний договір.

Актуальність теми. Ідея права як інструмента не $\epsilon$ новою. Без врахування інструментів у правовому механізмі неможливо ні впорядкувати суспільні відносини в межах конкретної галузі права залежно від їхнього інституціонального характеру, ні забезпечити фундамент для належного, ефективного та справедливого функціонального забезпечення реалізації конкретного правового механізму.

Установлення норм адміністративного права, які визначають адміністративно-правовий статус суб’єктів адміністративного права, формальна фіксація принципів адміністративного права так би й залишилися прописними істинами, які б ніколи не були реалізовані на практиці, якщо б в арсеналі суб'єктів публічної адміністрації не було належних й ефективних інструментів публічного адміністрування. Саме використовуючи їх, суб'єкти публічної адміністрації вступають в адміністративно-правові відносини і досягають бажаного для публічного адміністрування якнайповнішого забезпечення прав, свобод та законних інтересів приватних осіб публічного інтересу держави й суспільства загалом [1, с. 143].

Стан дослідження. Науковий аналіз проблематики інструментальної складової в адміністративно-правовому механізмі забезпечення фінансової безпеки держави виступав предметом дослідження таких науковців як: О. М. Бандурка, В. Т. Білоус, Ю. В. Гаруст, З. В. Гбур, О. М. Ілюшик, Т. А. Кобзєва, А. М. Куліш, В. І. Мельник, О. М. Музичук, С. І. Лекарь, О. І. Нікітенко, С. М. Ольховська, О. М. Рєзнік, Ю. С. Шемшученко та ін., які досліджували форми і методи діяльності правоохоронних органів як суб’єктів забезпечення економічної безпеки держави. Трансформація у сучасній адміністративно-правовій доктрині категорій “форми діяльності публічної адміністрації” та “методи діяльності публічної адміністрації” у категорію “інструменти публічного адміністрування" (“інструменти діяльності публічної адміністрації”) актуалізують дослідження саме інструментів адміністративно-правового забезпечення правоохоронними органами фінансової безпеки держави, що і виступає предметом нашого дослідження.

Виклад основного матеріалу. На думку І. В. Патерило, інструментом правового регулювання $\epsilon$ цінності права як увесь арсенал, увесь спектр 
правових феноменів різних рівнів, що відокремлюються та розглядаються не лише з позицій одних лише потреб юридичної практики, а з позицій їх функціонального призначення, тобто тих рис, які характеризують їх як інструменти розв'язання за їх допомогою економічних, політичних чи соціальних завдань [2]. У такому плані, на переконання С. С. Алексєєва, йдеться про спеціально-юридичний аспект інструментарію механізму правового регулювання, який охоплює увесь комплекс засобів, увесь юридичний інструментарій, що «працює»в процесі правового регулювання [3, с. 12]. Отже, можна стверджувати про існування у правовій доктрині широкого підходу до визначення категорії “правові інструменти”, згідно з яким інструменти - це весь комплексів засобів правового регулювання/ впливу.

Узагальнено інструмент публічного адміністрування може бути визначений як зовнішній вираз однорідних за своїм характером і правовою природою груп адміністративних дій суб'єктів публічної адміністрації, реалізований у межах суворої відповідності визначеної законом компетенції з метою досягнення бажаного для публічного адміністрування результату та характеризується такими ознаками: а) $є$ зовнішнім виразом форми адміністративної діяльності публічної адміністрації; б) відображає правову динаміку публічного адміністрування; в) залежить від змісту компетенцій суб'єктів публічної адміністрації; г) зумовлений реалізацією адміністративних обов'язків суб'єктів публічної адміністрації; д) його вибір зумовлюється специфікою поставленої мети щодо певного об'єкта публічного впливу, що встановлює найбільш ефективний варіант діяльності [1, c. 143-144].

Конкретні інструменти діяльності публічної адміністрації необхідно розкривати через призму системи її інституціонально-функціональних характеристик. На думку Р.С. Мельника, до інструментів діяльності публічної адміністрації включають нормативні акти публічної адміністрації, адміністративний акти та адміністративний договір [4, с. 9-10], а авторами підручника «Загальне адміністративне право», виданого за редакцією I.C. Гриценка, до переліку інструментів діяльності публічної адміністрації віднесено адміністративний акт, адміністративний договір, акти-дії, плани, приватно-правові інструменти, нормативні акти, адміністративний розсуд, електронне урядування [5, с. 559-564]. Колектив авторів підручника “Адміністративне право України. Повний курс", виданого у 2020 р., до інструментів публічного адміністрування відносить: нормативні акти, адміністративні акти, адміністративні договори, план та фактичні дії [1, с. 144]. Вважаємо, що саме ці п'ять різновидів інструментів публічного адміністрування використовуються правоохоронними органами в процесі забезпечення фінансової безпеки держави та зупинимося на перших трьох як базових.

На доктринальному рівні під нормативними актами розуміють: офіційний письмовий документ, який приймається уповноваженим органом, що встановлює, змінює або скасовує норми права [6, с. 20]; вид юридичного акта, який видано уповноваженим суб'єктом та який містить у собі норму (норми) адміністративного права [4, с. 253]; юридичний акт суб'єктів публічної адміністрації, що встановлює, змінює чи скасовує норми права 
- загальнообов'язкові правила поведінки, що встановлюються та охороняються державою [5, с. 379].

Можливо визначити ознаки нормативного акту: 1) є формою управлінської діяльності повноважного органу управління; 2) направляє свою дію в односторонньому порядку; 3) видається з дотриманням регламентованої процедури певних владних дій, передбачених законодавством чи на його виконання з метою реалізації відповідних завдань та функцій управління, що відображаються в остаточному підсумку в конкретну законну форму; 4) зумовлює настання певних юридичних наслідків [7, с. 144].

Отже, під нормативним актом як інструментом адміністративно-правового механізму забезпечення фінасової безпеки держави пропонуємо розуміти виданий уповноваженим суб'єктом юридичний акт, у якому закріплено норми адміністративного права, які регламентують відносини у фінансовій сфері між публічною адміністрацією та іншими суб'єктами, які мають публічний інтерес у цій сфері.

Слід зазначити, що нормативні акти як вид юридичних актів у правовій доктрині традиційно відносили до джерел права, але в останній час з'являтися тенденції до характеристики суто регуляторної та інструментальної природи актів суб’єктів публічної адміністрації, а розрізнювальним критерієм виступає відсоток правових норм загальнообов'язкового значення, які містяться в конкретному акті. При цьому Р.С. Мельник звертає увагу на таку закономірність: чим нижче розташований суб'єкт публічної адміністрації в адміністративній ієрархії, тим більше виданий ним нормативний акт нагадує інструмент діяльності. Натомість акти суб’єктів публічної адміністрації загальнодержавного рівня являють собою насамперед джерела адміністративного права [4, с. 253]. Розвиваючи цю тезу, Н.В. Галіцина визначає такі особливості нормативних актів як інструменту забезпечення: загальні формальні параметри, пов'язані 3 інституційно-процедурними аспектами (компетенція, порядок, форма i т.п.); спеціальні матеріальні параметри (публічність; адресність; юридична обгрунтованість і значущість; нормативність; односторонність; підзаконність; недискримінаційний характер). На основі цих характеристик у ракурсі непоширення категорії офіційності на ці акти їх можна відокремити від нормативно-правових актів як джерел адміністративного права [8, c. 327]. Вважаємо, що вище перелічені особливості нормативних актів $\epsilon$ цілком прийнятними і для сфери забезпечення фінансової безпеки держави.

Коли мова йде про нормативні акти як інструменти забезпечення фінансової безпеки держави, то маються на увазі підзаконні нормативно-правові акти, оскільки акти управління завжди $є$ підзаконними і покликані сприяти ефективній реалізації законів, деталізувати їх окремі норми, роз'яснювати порядок та особливості їх практичної реалізації, визначати алгоритм дії із ціллю забезпечити реальне й ефективне виконання всіх поставлених завдань.

Повноваження правоохоронних органів приймати підзаконні нормативно-правові акти передбачені законодавством України. Зокрема, керівники органів, підрозділів, закладів та установ Національної поліції України, у межах повноважень, визначених законом, іншими нормативними актами, та номенклатурою посад, затвердженою Міністерством внутрішніх 
справ України, можуть видавати накази по особовому складу [9, ч. 4 ст. 53]; Центральне управління Служби безпеки України уповноважене видавати накази, розпорядження, положення, інструкції, давати обов'язкові для виконання у системі Служби безпеки України вказівки [10, ч. 2 ст. 10]; до повноважень Директора Національного антикорупційного бюро віднесено видачу, у межах повноважень, наказів і розпоряджень, а також надання доручень, які є обов'язковими для виконання працівниками бюро [11, п. 5 ч. 1 ст. 8]; Генеральний прокурор з питань, що належать до його адміністративних повноважень, уповноважений видавати накази у межах своїх повноважень, на основі та на виконання Конституції і законів України [12, ч. 2 ст. 9].

Адміністративні акти за своїми сутнісними рисами є новою категорією для доктрини адміністративного права, зміст яких розкривається через повноваження публічної адміністрації, і $\epsilon$ наслідком імплементації законодавства України до права Європейського Союзу, що обумовило перехід від використання терміна «акт державного управління» до поняття «адміністративний акт». Зокрема, у Резолюції (77) 31 Комітету міністрів Ради Європи державам - членам про захист особи відносно актів адміністративних органів надається визначення адміністративного акта як «захід і прийняте рішення» [13]. На відміну від України, на національному рівні європейських країн існує тенденція щодо визначення терміну «адміністративний акт» у широкому значенні: до адміністративних актів відносяться усі акти адміністрації, як індивідуальні акти публічної адміністрації, так і адміністративні договори та нормативні акти (у Франції); будь-який прояв діяльності уповноваженого органу, який стосується врегулювання індивідуального (окремого) питання у публічній сфері (у німецькому Законі «Про адміністративну процедуру») [14]. При цьому для Європи визначальними сутнісними характеристиками цього терміна $\epsilon$ функціональна складова (постає як процес і результат), інституціональний критерій (охоплює нормативні та індивідуальні акти, а також адміністративні договори) і предметний вимір (визначається за сферами, на які поширюється дія акта) [8, c. 345].

В Україні до визначення поняття “адміністративний акт" застосовується вузький підхід, закріплений рішеннями Конституційного суду України, зокрема, рішенням Конституційного Суду України від 23 червня 1997 р., де передбачено, що за своєю природою встановлюють конкретні приписи, звернені до конкретного індивіда чи юридичної особи, що застосовуються одноразово [15], та рішенням Конституційного Суду України від 22 квітня 2008 р., у якому йдеться про те, що адміністративні акти $\epsilon$ актами індивідуальної дії, розрахованими на персональне (індивідуальне) застосування та після їх реалізації вичерпують свою дію [16].

Науковцями адміністративний акт визначається як: волевиявлення адміністративного органу щодо вирішення адміністративної справи, спрямоване на виникнення, зміну чи припинення прав та обов'язків конкретних фізичних або юридичних осіб» (В. П. Тимощук) [17, с. 33]; рішення індивідуальної дії, яке прийняте адміністративним органом і спрямоване на вирішення конкретної адміністративної справи, що тягне за собою настання певних юридичних наслідків (Д. В. Лученко та М. І. Бєлікова) [18, с. 51]; 
розпорядження (рішення) суб’єкта публічної адміністрації, яке спрямоване на регулювання окремого (конкретного) випадку у сфері публічного адміністрування і яке тягне юридичні наслідки» (Р. С. Мельник) [4, с. 263]; вчинене у письмовій або конклюдентній формі рішення, дія, бездіяльність суб'єкта владних повноважень (суб'єкта публічної адміністрації) у зв'язку з виконанням цим суб’єктом його компетенції (В. М. Бевзенко) [19, с. 14-15].

До ознак, як характеризують адміністративний акт, віднесено: а) індивідуальність (конкретність); б) це акт адміністративного органу суб'єкта, наділеного адміністративними повноваженнями, тобто повноваженнями з розгляду та вирішення адміністративної справи та вчинення спрямованих на це дій; в) прямий вплив на приватних осіб, тобто зовнішня дія адміністративного акту [18, с. 52].

3 огляду на викладене та відсутність легальної дефініції адміністративного акта в Україні, прийнятними в межах нашого дослідження $є$ розуміння сутності адміністративного акта як рішення суб'єкта публічної адміністрації щодо вирішення конкретної адміністративної справи, що тягне юридичні наслідки для конкретних фізичних і юридичних осіб. Ця ж дефініція відповідає сутності досліджуваного інструмента діяльності публічної адміністрації в частині забезпечення фінансової безпеки держави.

Можливість видання адміністративних актів правоохоронними органами закріплена на законодавчому рівні. Наприклад, відповідно до Положення про Національну поліцію, затвердженого постановою Кабінету Міністрів України, від 28 жовтня 2015 р. № 877, Національна поліція в межах повноважень, передбачених законом, на основі та на виконання Конституції та законів України, актів Президента України та постанов Верховної Ради України, прийнятих відповідно до Конституції та законів України, актів Кабінету Міністрів України, наказів Міністерства внутрішніх справ видає накази організаційно-розпорядчого характеру, організовує та контролює їх виконання [20, п. 9].

3 метою забезпечення фінансової безпеки держави публічна адміністрація може використовувати й такий інструмент, як адміністративні договори, легальна дефініція якого міститься у Кодексі адміністративного судочинства України [21], відповідно до п. 14 ст. 3 якого адміністративний договір - це дво- або багатостороння угода, зміст якої складають права та обов'язки сторін, що випливають із владних управлінських функцій суб'єкта владних повноважень, який є однією із сторін угоди.

У сучасній адміністративно-правовій доктрині адміністративний договір трактується як: визначена актами адміністративного права угода сторін, одна з яких є носієм державно-владних повноважень стосовно інших [22, с. 120]; різновид публічного договору, який стосується добровільного волевиявлення сторін, однією з яких є орган влади або суб'єкт, якому делеговано владні управлінські функції, та укладається з метою реалізації цими суб'єктами владних управлінських функцій без застосування примусу до виконання зобов'язань іншою стороною [23, с. 98]; угода, заснована на адміністративно-правових нормах і вироблена внаслідок добровільного узгодження волі між двома (чи більше) державно-владними суб'єктами адміністративного права та іншими організаціями, з приводу спільної реалізації покладених на них повноважень [24, с. 73]; дво- або багатосторон- 
ня угода, зміст якої становлять права та обов'язки сторін, що випливають із владних управлінських функцій суб'єкта владних повноважень, який $\epsilon$ однією із сторін угоди $[19$, с. 17]; спільний правовий акт суб'єктів владних повноважень або правовий акт за участю суб'єкта владних повноважень та іншої особи, що грунтується на їх волеузгодженні, має форму договору, угоди, протоколу, меморандуму тощо, визначає взаємні права та обов'язки його учасників у публічно-правовій сфері в укладається на підставі закону: а) для розмежування компетенції чи визначення порядку взаємодії між суб'єктами владних повноважень; б) для делегування публічно-владних управлінських функцій; в) для перерозподілу або об'єднання бюджетних коштів у випадках, визначених законом; г) замість видання адміністративного акта; д) для врегулювання питань надання адміністративних послуг [18, с. 54]. На наш погляд, саме останнє визначення, наведене у Великій українській юридичній енциклопедії (2020), найбільш повно відображає сутність адміністративного договору як інструмента публічного адміністрування.

Виділяються такі ознаки адміністративного договору: 1) одним із учасників адміністративного договору обов'язково $є$ суб'єкт владних повноважень; 2) змістом адміністративного договору $є$ права та обов'язки його учасників у публічній правовій сфері; 3) укладається на підставі закону, тобто право суб'єкта владних повноважень укласти адміністративний договір має бути передбачене саме законом, а не підзаконними актами; 4) реалізується, як правило, на нормах адміністративного права; 5) викликає безпосереднє настання юридичних наслідків у вигляді виникнення, зміни й припинення правовідносин (меморандум про співпрацю), виникнення зміни, припинення прав і обов'язків його учасників (договори про розстрочення та відстрочення грошових зобов'язань або податкового боргу платника податків) у публічній сфері; 6) метою адміністративного договору є задоволення публічних інтересів; 7) адміністративний договір оформлює ті суспільні відносини, які входять до предмета адміністративного права [25].

Ознаками адміністративного договору у сфері правоохоронної діяльності, на думку С. М. Ольховської, є наступні: 1) виникає у сфері реалізації виконавчої влади, у зв'язку та з приводу реалізації органами внутрішніх справ наданих йому виконавчо-розпорядних повноважень; 2) підставою виникнення договору є владний, імперативний припис органів внутрішніх справ; 3) мета договору виражається в його спрямованості на конкретизацію відповідних адміністративно-правових норм або актів правозастосовної діяльності органів внутрішніх справ, у зв'язку з чим він має організуючий характер [26, с. 12].

О. М. Ілюшик серед ознак адміністративного договору у правоохоронній сфері виділяє такі: 1) обов'язковою стороною адміністративного договору є правоохоронний орган як суб'єкт владних повноважень; 2) змістом (предметом) адміністративного договору $\epsilon$ права та обов'язки сторін, пов'язані з реалізацією правоохоронним органом владних управлінських функцій; 3) метою укладання адміністративного договору $є$ реалізація функцій держави, а саме реалізація повноважень правоохоронного органу, тобто, укладаючи відповідний договір, правоохоронний орган діє 
не для задоволення особистих потреб (як фізичної чи юридичної особи), а для задоволення публічних інтересів; 4) правовою основою укладення адміністративного договору є норми адміністративного права; 5) сторони адміністративного договору є формально рівними; 7) адміністративний договір у діяльності правоохоронних органів має організаційний характер; 8) наявність застереження про виключні повноваження правоохоронного органу як представника публічної адміністрації. При цьому дослідниця перші три ознаки відносить до основних ознак адміністративного договору, а решту - до факультативних [27, с. 103-105].

Серед різновидів адміністративних договорів, що укладаються в процесі діяльності Служби безпеки України, Національного антикорупційного бюро України, Національної поліції України, підрозділів податкової міліції Державної фіскальної служби України, а також органів прокуратури України як суб'єктів, уповноважених забезпечувати фінансову безпеку країни, можливо виокремити дві їх групи: 1) координаційні договори, якими є організаційний договір (договір про делегування повноважень), договір про співпрацю правоохоронних органів між собою, договір про взаємодію правоохоронних органів з іншими органами публічної влади та недержавними організаціями; 2) субординаційні договори, до яких належать: договір про вступ громадян на службу до правоохоронного органу, виконання окремих завдань правоохоронної спрямованості, договір про публічні послуги; податкові та митні угоди [28, с. 10; 29, с. 293-294].

Отже, фундаментальними ознаками адміністративного договору у сфері фінансової безпеки держави є наявність публічної адміністрації як однієї зі сторін такої угоди, а також сутнісні характеристики щодо обумовлення повноважень сторін договору на основі владно-управлінської функції. Іншими факультативними специфічними інструментальними рисами адміністративного договору в фінансовій сфері $\epsilon$ орієнтація на задоволення публічного інтересу та суспільних потреб у фінансовій безпеці, законодавчі процедурні рамки діяльності суб’єкта публічної адміністрації, спрямованої на реалізацію його адміністративної компетенції.

\section{СПИСОК ВИКОРИСТАНИХ ДЖЕРЕЛ}

1. Адміністративне право України. Повний курс : підручник / Галунько В., Діхтієвський П., Кузьменко О.та ін. / за заг. ред. В. Галунька, О. Правотворової. Видання третє. Херсон: ОЛДІ-ПЛЮС, 2020. 584 с.

2. Патерило I. В. Право як ціннісна категорія : автореф. дис. ... канд. юрид. наук : 12.00.01. К. : Ін-т держави і права ім. В.М. Корецького, 2006. 20 с.

3. Алексеев С. С. Общая теория права : монография : в 2 т. Т. 2 : Технико-юридическое содержание права. М. : Юридическая литература, 1982. $360 \mathrm{c}$.

4. Мельник Р. С. Загальне адміністративне право : навч. посіб. / Р. С. Мельник, В. М. Бевзенко ; за заг. ред. Р. С. Мельника. К. : Ваіте, 2014. $376 \mathrm{c}$.

5. Загальне адміністративне право : підручник / I. С. Гриценко, Р. С. Мельник, А. А. Пухтецька та ін. ; за заг. ред. І. С. Гриценка. К. : Юрінком Інтер, 2015. 568 c. 
6. Сучасна правова енциклопедія / О. В. Зайчук, О. Л. Копиленко, Н. М. Оніщенко ; за заг. ред. О. М. Зайчук. К. : Юрінком Інтер, 2010. 384 с.

7. Авер'янов В. Б. Державне управління : проблеми адміністративноправової теорії та практики / за заг. ред. В. Б. Авер'янова. К. : Факт, 2003. $384 \mathrm{c}$.

8. Галіцина Н. В. Теорія та практика реалізації концепції соціальної держави в Україні : адміністартивно-правове дослідження : монографія. Харків : ФОП Панов, 2016. 578 с.

9. Про Національну поліцію: Закон України № 580-VIII від 02.07.2015 p. Відомості Верховної Ради України. 2015. № 40-41. Ст. 379.

10. Про Службу безпеки України: Закон України № 2229-XII від 25.03.1992 р. Відомості Верховної Ради України. 1992. № 27. Ст. 382.

11. Про Національне антикорупційне бюро України: Закон України від 14.10.2014 р. № 1698-VII. Відомості Верховної Ради України. 2014. № 47. Ст. 2051.

12. Про прокуратуру: Закон України від 14.10.2014 р. Відомості Верховної Ради України. 2015. № 2-3. Ст. 12.

13. Резолюція (77) 31 Комітету міністрів Ради Європи державам членам про захист особи відносно актів адміністративних органів від 28 вересня 1977 р. Адміністративна процедура та адміністративні послуги. Зарубіжний досвід та пропозицї для України [автор-упорядник В. П. Тимощук]. К. : Факт, 2003. С. 469-479.

14. Ященко Т. В. Актуальні проблеми законодавчого закріплення поняття «адміністративний акт». Часопис Київського університету права. 2014. № 1. С. 395-400.

15. Рішення Конституційного Суду України у справі щодо відповідності Конституції України (конституційності) положення підпункту 2 пункту 3 розділу IV Закону України «Про Конституційний Суд України» стосовно правових актів органів Верховної Ради України (справа про акти органів Верховної Ради України) від 23 червня 1997 р. № 2-зп. Офіційний вісник України. 1997. № 27. С. 155.

16. Рішення Конституційного Суду України у справі за конституційним поданням 52 народних депутатів України та за конституційним поданням Верховної Ради Автономної Республіки Крим щодо відповідності Конституції України (конституційності) статті 15 Кодексу адміністративного судочинства України, статті 7 Цивільного процесуального кодексу України (справа про мову судочинства) від 22 квітня 2008 р. № 8-рп/2008. Офіційний вісник України. 2008. № 33. С. 64. Ст. 1103.

17. Тимощук В. П. Адміністративні акти : процедура прийняття та припинення дії : монографія. К. : Конус-Ю, 2010. 296 с.

18. Велика українська юридина енциклопедія : у 20 т. Т. 5 : Адміністративне право / редкол. : Ю. П. Битяк (голова) та ін. Харків : Право, 2020.960 с.

19. Адміністративне право України : словник термінів / за заг. ред. Т. О. Коломоєць, В. К. Колпакова. К. : Ін Юре, 2014. 520 с.

20. Про затвердження Положення про Національну поліцію : постанова Кабінету Міністрів України від 28.10.2015 p. № 877. URL : http://www. kmu. gov.ua/control/ru/cardnpd?docid=248607704. 
21. Кодекс адміністративного судочинства України. Відомості Верховної Ради України. 2005. № 35-36, № 37. Ст. 446.

22. Коломоєць Т. О. Адміністративний примус у публічному праві України : теорія, досвід, та практика реалізації : монографія. Запоріжжя: Поліграф, 2004. 404 с.

23. Смокович М. І. Визначення юрисдикції адміністративних судів та розмежування судових юрисдикцій : монографія. К. : Юрінком Інтер, 2012. $304 \mathrm{c}$.

24. Токар А. М. Адміністративний договір як форма управлінської діяльності (питання теорії). Держава і право. 2001. № 13. С. 72-74.

25. Завальна Ж. Порівняльний аналіз адміністративного та цивільного договорів. Право Украӥни. 2007. № 3. С. 135-139.

26. Ольховська С. М. Процедури укладення та виконання адміністративних договорів у практиці органів внутрішніх справ. Вісник ХНУВС. 2011. Вип. 54. С. 237-241.

27. Ілюшик О. М. Ознаки адміністративного договору, що використовується у діяльності правоохоронних органів. Право і громадянське суспільство. 2014. № 1. С. 98-108.

28. Ілюшик О. М. Використання адміністративних договорів у діяльності правоохоронних органів : автореф. ... канд. юрид. наук : 12.00.07. Львів, 2013. 19 с.

29. Резнік О. М. Адміністративно-правові засади діяльності правоохоронних органів із забезпечення фінансово-економічної безпеки України : дис.... докт. юрид. наук : 12.00.07. Суми, 2019. 509 с.

\section{Liukh}

\section{INSTRUMENTS OF ADMINISTRATIVE AND LEGAL ENSURING THE FINANCIAL SECURITY OF THE STATE}

The article is devoted to the analysis of the problems of the instrumental component in the administrative and legal mechanism of ensuring the financial security of the state. It is emphasized that the transformation in the modern administrative and legal doctrine of the categories "forms of public administration" and "methods of public administration" into the category "tools of public administration" actualizes the research of instruments of administrative and legal support by law enforcement agencies. It is established that modern legal doctrine applies a broad approach to defining the category of "legal instruments", according to which instruments are the whole set of legal regulations/influence, and proposed specific tools for public administration to disclose through the prism of its institutional and functional characteristics. It is determined that law enforcement agencies in the process of ensuring the financial security of the state use such tools of public administration as regulations, administrative acts, administrative agreements, plans and actual actions. Under the normative act as an instrument of administrative and legal mechanism to ensure the financial security of the state proposed to understand the legal entity issued by the authorized entity, which enshrines the rules of administrative law governing relations in the financial sphere between public administration and other entities with public interest in in this area. The peculiar- 
ities of normative acts as a tool of provision are highlighted: general formal parameters related to institutional and procedural aspects (competence, procedure, form, etc.); special material parameters (publicity; targeting; legal validity and significance; normativeness; unilaterality; by-laws; non-discriminatory nature). It is noted that administrative acts by their essential features are a new category for the doctrine of administrative law, the content of which is disclosed through the powers of public administration, and is a consequence of the implementation of Ukrainian legislation to European Union "law administrative act". Given the lack of a legal definition of an administrative act in Ukraine, as a basic understanding of the essence of an administrative act as a decision of a public administration to resolve a specific administrative case, which entails legal consequences for specific individuals and legal entities, which corresponds to the essence of the investigated public instrument. administration in terms of ensuring the financial security of the state. The fundamental features of the administrative agreement in the field of financial security of the state - the presence of public administration as one of the parties to such an agreement, as well as the essential characteristics for determining the powers of the parties to the agreement on the basis of power management function. Other optional specific instrumental features of the administrative agreement in the financial sphere are the focus on meeting the public interest and public needs in financial security, the legislative procedural framework of the public administration aimed at implementing its administrative competence.

Keywords: public administration, financial security of the state, legal instrument, instrument of administrative and legal support, law enforcement body, normative act, administrative act, administrative agreement. 